\title{
Controlling second coordination sphere effects in luminescent ruthenium complexes by external pressure
}

\author{
Andrea Pannwitz, ${ }^{[a]+}$ Stéphanie Poirier, ${ }^{[b]+}$ Nicolas Bélanger-Desmarais, ${ }^{[b]}$ Alessandro Prescimone, ${ }^{[c]}$ \\ Oliver S. Wenger, ${ }^{*[a]}$ Christian Reber* ${ }^{[b]}$
}

\begin{abstract}
Two luminescent heteroleptic Ru(II) complexes with a 2,2'biimidazole $\left(\right.$ biim $\left._{2}\right)$ ligand form doubly hydrogen-bonded salt bridges to 4-sulfobenzoate anions in single crystals. The structure of one of these cation-anion adducts shows that the biimH $_{2}$ ligand is deprotonated. Its ${ }^{3} \mathrm{MLCT}$ luminescence bands does not shift significantly under the influence of an external hydrostatic pressure, a behavior typical for these electronic transitions. In contrast, hydrostatic pressure on the other crystalline cation-anion adduct induces a shift of proton density from the peripheral $\mathrm{N}-\mathrm{H}$ groups of biimH $_{2}$ towards benzoate, leading to a pronounced red-shift of the ${ }^{3} \mathrm{MLCT}$ luminescence band. Such a significant and pressure-tuneable influence from an interaction in the second coordination sphere is unprecedented in artificial small molecule-based systems.
\end{abstract}

Atoms or groups that are not directly bonded to a metal center, but to the outer periphery of the ligands, can have a crucial influence on the properties of a complex. Such second coordination sphere effects play an important role in many proteins, but in artificial systems they are usually difficult to emulate. For instance, in blue copper enzymes certain amino acid point mutations in the second coordination sphere of the active site have a remarkable influence on its redox potential, but in small synthetic complexes this cannot be modeled easily. ${ }^{[1]}$ The importance of controlling the second coordination sphere in small metal complexes has been widely recognized in recent years, as it has been found that the performance of certain artificial catalysts for $\mathrm{H}_{2}$ generation and $\mathrm{CO}_{2}$ reduction crucially depends on the presence of proton relay stations. ${ }^{[2]}$ In artificial metalloenzymes, second coordination sphere effects have been exploited to influence the enantio- or diastereo-selectivity of chemical reactions. ${ }^{[3]}$

[a] A. Pannwitz, Prof. Dr. O. S. Wenger, Department of Chemistry, University of Basel, St. Johanns-Ring 19,4056 Basel (Switzerland)

E-mail: oliver.wenger@unibas.ch

[b] S. Poirier, N. Bélanger-Desmarais, Prof. Dr. C. Reber Département de chimie, Université de Montréal, Montréal, Québec H3C 3J7, (Canada).

E-mail: christian.reber@umontreal.ca

[c] Dr. A. Prescimone

Department of Chemistry, University of Basel, Mattenstrasse 24a BPR 1096, 4058 Basel (Switzerland).

[+] These authors contributed equally to this work. Supporting information and the ORCID identification number(s) for the author(s) of this article can be found under XXX. It contains a description of equipment and methods, as well as syntheses, product characterization data and crystallographic tables. CCDC 1583830 and CCDC 1583965 (for Ru( $\left.{ }^{t} \mathrm{Bu}\right)$ ), and CCDC 1583848 and CCDC 1583964 (for $\mathrm{Ru}\left(\mathrm{CF}_{3}\right)$ ) contain the supplementary crystallographic data for this paper. These data can be obtained free of charge from The Cambridge Crystallographic Data Centre.
Our approach for controlling the three-dimensional structure beyond the first coordination sphere is to employ hydrogenbonding motifs in single crystals of luminescent ruthenium complexes. These noncovalent interactions give access to highly ordered and precise arrangements of individual molecular components and we decided to use the 1:1 adducts that can be formed between complexes bearing a biimH $\mathrm{b}_{2}$ ligand and a carboxylate counterion. ${ }^{[4]}$ Such hydrogen bonded adducts are readily accessible in apolar solution, but in the following we focus on the solid state, where hydrogen bonds depend on the threedimensional packing and on the charge balance of the compounds. ${ }^{[5]}$ With the dicationic Ru(II) complexes from Figure 1a/b such 1:1 adducts can be obtained when crystallizing them with the dianionic 4-sulfobenzoate. These heteroleptic $\mathrm{Ru}(\mathrm{II})$ complexes with biim $\mathrm{H}_{2}$ and bpy ligands commonly exhibit photoluminescence from the lowest ${ }^{3} \mathrm{MLCT}$ excited states which is sensitive to the interactions of the biimH ${ }_{2}$ ligand with Brönsted bases in the second coordination sphere. ${ }^{[6]}$ By applying external pressure on the crystalline 1:1 adducts we varied the biimH $_{2}-$ benzoate distance and followed changes of the protonation state by luminescence spectroscopy.

Increasing pressure leads to a continuous variation of proton delocalization across the salt bridge and a continuous shift of the luminescence maximum in one of the two adducts. To the best of our knowledge, there exist no prior studies that demonstrate such direct and continuous control of a second coordination sphere effect.

$\mathrm{Ru}(\mathrm{II})$ biim $\mathrm{H}_{2}$ complexes with either ${ }^{\mathrm{t}} \mathrm{Bu}$ or $\mathrm{CF}_{3}$ substituents on the bpy spectator ligands were synthesized and crystallized as 4sulfobenzoate salts (Figure 1, synthesis and crystallization in the $\mathrm{SI}$ on pages S4 - S7), hereafter referred to as $\mathrm{Ru}\left({ }^{t} \mathrm{Bu}\right)$ and $\mathrm{Ru}\left(\mathrm{CF}_{3}\right)$. The single crystal X-ray structures of both compounds at $300 \mathrm{~K}$ are presented in Figure $1 \mathrm{c}-\mathrm{d}$. $\mathrm{Ru}\left({ }^{\mathrm{t}} \mathrm{Bu}\right)$ crystallized in the monoclinic space group $P 2_{1} / c$ with one cation-anion pair in the asymmetric unit, and $\mathrm{Ru}\left(\mathrm{CF}_{3}\right)$ crystallized in the triclinic space group $P 1$ with two isomers per unit cell, one of which is shown in Figure $1 \mathrm{~d}$ and the second one is shown in Figure S6 of the SI. The hydrogen bonding distances between the two peripheral biim $_{2} \mathrm{~N}$-atoms and the two O-atoms of the carboxylate group are in the typical range for such hydrogen bonds (2.58(2) 2.674(3) A)..$^{[6 \mathrm{~d}, ~ e, ~ 7] ~ T h e ~}$ biim $_{2}$ ligand and the carboxylate plane are at an angle of $12.4^{\circ}$ in $\mathrm{Ru}\left({ }^{\mathrm{t}} \mathrm{Bu}\right)$ and at $34.7^{\circ}$ and $26.1^{\circ}$ in $\mathrm{Ru}\left(\mathrm{CF}_{3}\right)$, with the overall arrangement clearly indicative of twofold $\mathrm{N} \cdots \mathrm{H} \cdots \mathrm{O}$ hydrogen bonding in both structures, in line with prior studies of related systems. ${ }^{[5]}$ The most important difference between the two compounds is the protonation state of the biim $\mathrm{H}_{2}$ ligand in the crystal structure. In the case of $\mathrm{Ru}\left({ }^{t} \mathrm{Bu}\right)$, the biim $\mathrm{H}_{2}$ ligand is fully protonated (solid lines marking the $\mathrm{N}-\mathrm{H}$ bonds in Fig. 1a) whereas for the $\mathrm{Ru}\left(\mathrm{CF}_{3}\right)$ structure only one $\mathrm{N}-\mathrm{H}$ bond 
could clearly be found in the electron density map (dashed line marking one of the $\mathrm{N}-\mathrm{H}$ bonds in Fig. $1 \mathrm{~b}$ ). In this crystal structure, the exact position of the second hydrogen

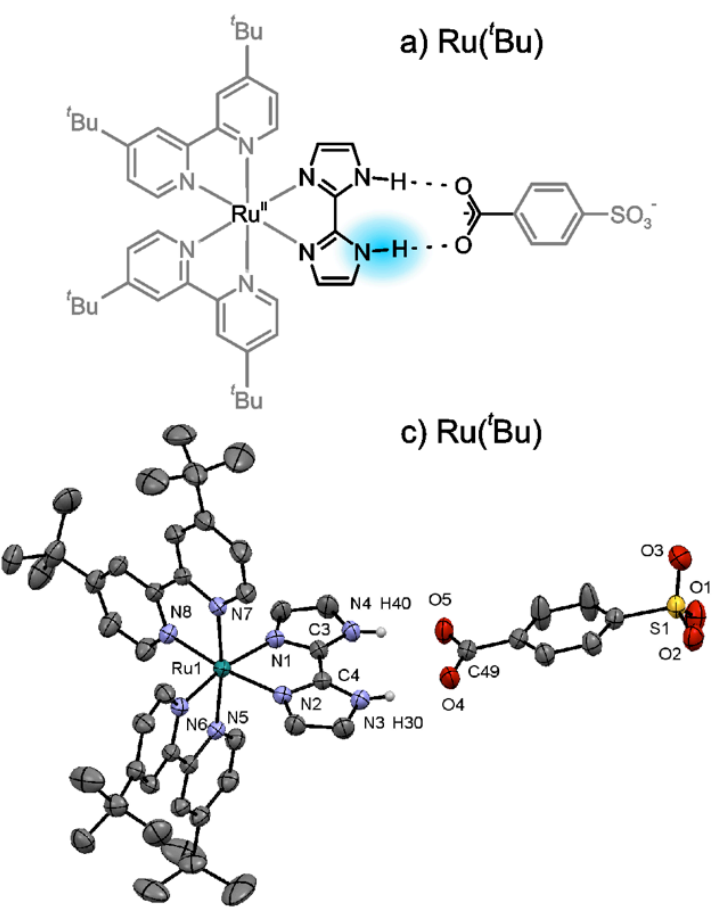

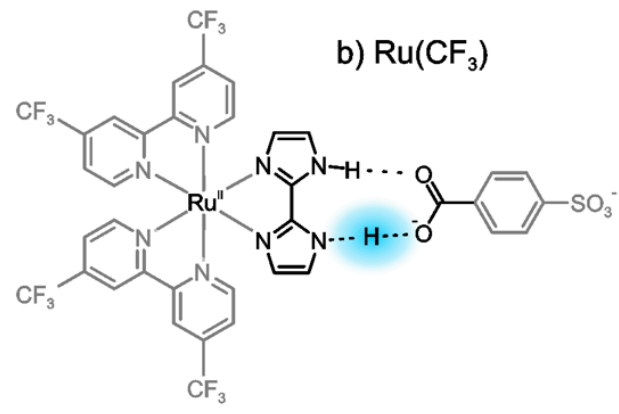

d) $\mathrm{Ru}\left(\mathrm{CF}_{3}\right)$

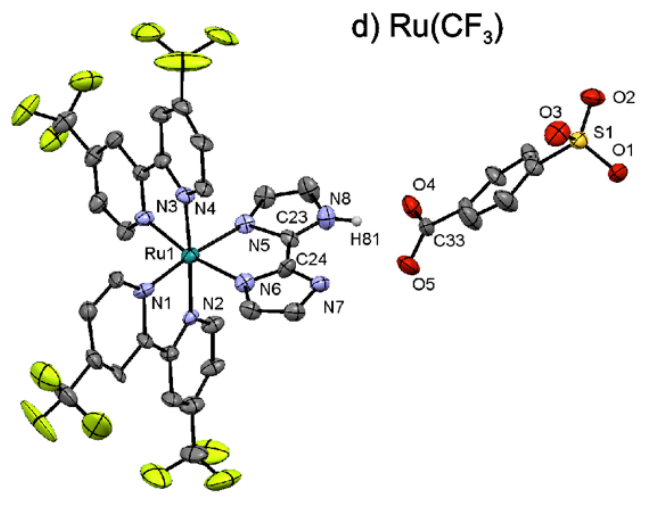

Figure 1. (a) Lewis structures of the $1: 1$ adducts between $\mathrm{Ru}\left(\mathrm{R}\right.$-bpy) ${ }_{2}\left(\mathrm{biimH}_{2}\right)^{2+}$ complexes and 4-sulfobenzoate: (a) $\mathrm{Ru}\left({ }^{\left({ }^{\mathrm{B} u}\right.}\right)$ and $(\mathrm{b}) \mathrm{Ru}\left(\mathrm{CF}_{3}\right)$. Single crystal $\mathrm{X}$-ray structures at $300 \mathrm{~K}$ of (c) $\mathrm{Ru}\left({ }^{\mathrm{t}} \mathrm{Bu}\right.$ ) and (d) $\mathrm{Ru}\left(\mathrm{CF}_{3}\right)$ (isomer 1, isomer 2 is shown in the Figure $\mathrm{S} 6$ of the SI). Thermal ellipsoids are drawn at $30 \%$ probability. Hydrogen atoms are omitted for clarity, except for hydrogen atoms involved in the $\mathrm{N}-\mathrm{H} \cdots$ O hydrogen bond that were found in the electron density map.

atom within the $\mathrm{N} \cdots \mathrm{H} \cdots \mathrm{O}$ hydrogen bond in this case is more compatible with delocalization of one proton between biimH $_{2}$ and the carboxylate group.

This key finding is compatible with the higher acidity of the biimH ligand for the more electron-deficient $\mathrm{Ru}\left(\mathrm{CF}_{3}\right)$ complex (see $\mathrm{SI}$ page S13 for details).

Following excitation at $488 \mathrm{~nm}$, single crystalline samples of $\mathrm{Ru}\left({ }^{\mathrm{t}} \mathrm{Bu}\right)$ and $\mathrm{Ru}\left(\mathrm{CF}_{3}\right)$ both exhibit ${ }^{3} \mathrm{MLCT}$ luminescence (Figure $2 \mathrm{a} / \mathrm{b}$ ). According to DFT calculations (SI pages S14 - S26), the $\mathrm{HOMO}$ is metal-based with some biimH $\mathrm{H}_{2}$ contribution, whereas the LUMO and the LUMO+1 are predominantly bpy-centered in both cases, with the LUMO of Ru( ${ }^{\mathrm{t}} \mathrm{Bu}$ ) showing a more important biimH $_{2}$ contribution, as seen in Figure S9 of the SI. The luminescence band maximum in $\mathrm{Ru}\left(\mathrm{CF}_{3}\right)$ is $\sim 800 \mathrm{~cm}^{-1}$ lower in energy than in $\mathrm{Ru}\left({ }^{\mathrm{t}} \mathrm{Bu}\right)$, compatible with a more stabilized LUMO due to the electron-withdrawing $\mathrm{CF}_{3}$ substituents on bpy and a more destabilized HOMO due to proton delocalization into the hydrogen bond (see below for further details).

When applying hydrostatic pressure in a diamond anvil cell (SI page S2), the two compounds exhibit markedly different changes in luminescence behavior. $\mathrm{Ru}\left(\mathrm{CF}_{3}\right)$ behaves similarly to the $\mathrm{Ru}(\mathrm{bpy}) \mathrm{3}^{2+}$ complex showing a very weak variation of the emission band maximum $\left(E_{\max }\right)$ with pressure (Figure $2 b$ ). Between ambient pressure and $36 \mathrm{kbar}, \mathrm{E}_{\max }$ stays constant within the experimental error with an average value of $14120 \mathrm{~cm}^{-1}$ (Figure 2c), showing that the luminescence of $\mathrm{Ru}\left(\mathrm{CF}_{3}\right)$ is pressureindependent (squares and dotted line in Figure 2c). For comparison, $E_{\max }$ values for $\mathrm{Ru}(\mathrm{bpy})_{3}{ }^{2+}$ shift in the range of -2 to $8.5 \mathrm{~cm}^{-1} / \mathrm{kbar}$ depending on pressure regimes and solid state matrix. ${ }^{[8]}$ The relative pressure insensitivity of the luminescence for both $\mathrm{Ru}(\mathrm{bpy})_{3}{ }^{2+}$ and $\mathrm{Ru}\left(\mathrm{CF}_{3}\right)$ is similar and typical for MLCT transitions in octahedral $d^{6}$ metal complexes. ${ }^{[8 a]}$ In marked contrast, $\mathrm{Ru}\left({ }^{\mathrm{t}} \mathrm{Bu}\right)$ shows a constant shift of $E_{\max }$ by $-13 \pm 1 \mathrm{~cm}$ $1 / \mathrm{kbar}$ between ambient pressure and $55 \mathrm{kbar}$ (spectra in Figure $2 \mathrm{a}$ and circles in Figure 2c). Pressure-induced red shifts of comparable magnitude have been reported for square-planar $\mathrm{Pd}$ (II) complexes, where a non-coordinated alkyl group interacts with the metal center, also an effect other than straightforward first-sphere metal-ligand bonding. ${ }^{[9]}$ The strongest pressureinduced shifts occur for stacked square-planar Pt(II) complexes, with values of -115 to $-320 \mathrm{~cm}^{-1} / \mathrm{kbar}$ due to intermolecular metalmetal interactions ${ }^{[10]}$ In both literature cases, the red shift is due to a destabilization of the metal-based HOMO. In our case, an interaction directly on the metal is not possible due to the saturated coordination sphere, but the hydrogen bonding influences the electronic structure of the first coordination sphere. Previous studies of biim $\mathrm{H}_{2}$ complexes show a strong variation of HOMO energies with the protonation state of the ligand. ${ }^{[6 a-d]}$ DFT 
calculations for the protonated and deprotonated $\mathrm{Ru}\left({ }^{\mathrm{t}} \mathrm{Bu}\right)$ complex have been carried out to model the variations of HOMO, LUMO energies with deprotonation. These variations are expected to go in the same direction as the pressure-induced shifts since pressure reduces intermolecular distances and therefore significantly changes hydrogen bonding. The calculations illustrated in Fig. S10 in the SI clearly show that HOMO has metal " $\mathrm{t}_{2 \mathrm{~g}}$ " character. Upon deprotonation, biimH $\mathrm{H}_{2}$ becomes a strong $\pi$ donor, leading to the destabilization of the metal-based HOMO, documented by the orbital energies in Table S8 in the SI. The calculated LUMO and LUMO+1 of the deprotonated complex are predominantly bpy based, as shown in Fig. S10. This

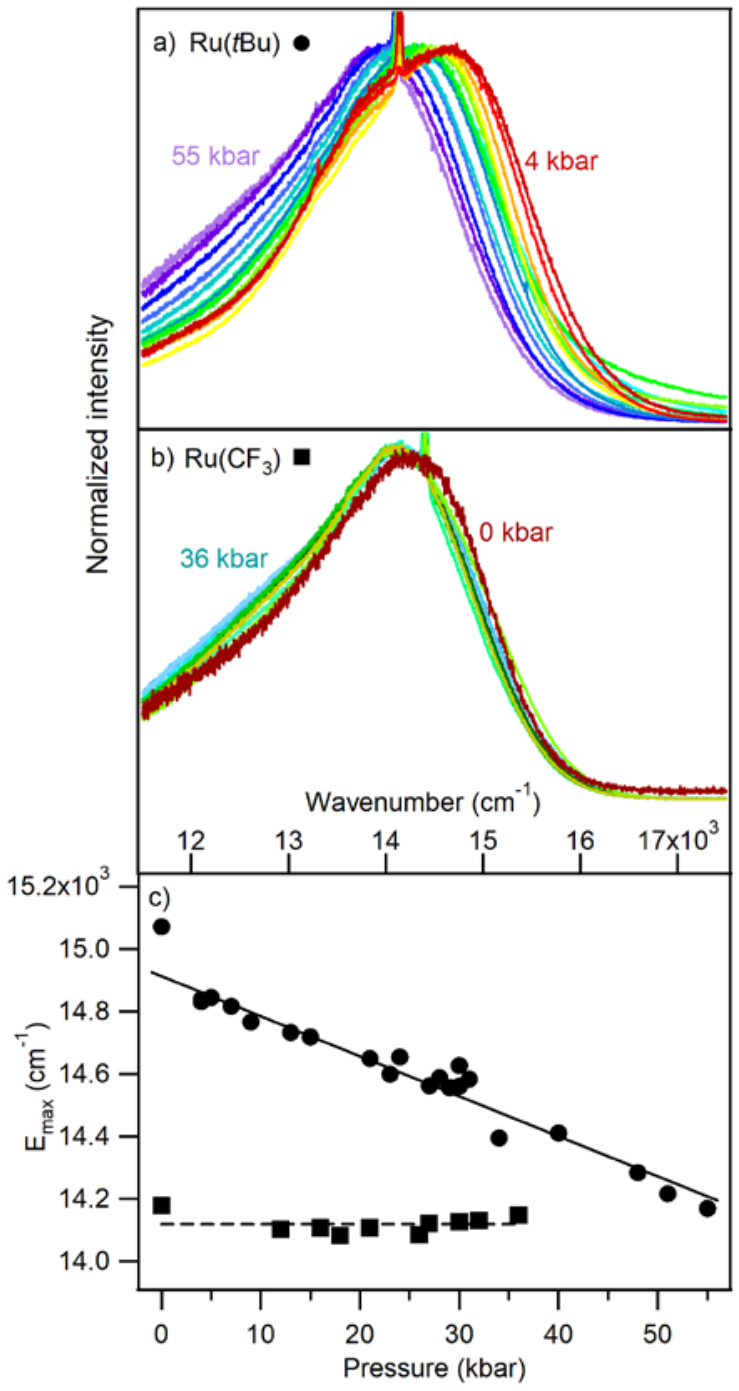

destabilization leads to a calculated HOMO-LUMO energy gap smaller by $20 \%$ for the deprotonated $\mathrm{Ru}\left({ }^{t} \mathrm{Bu}\right)$ complex, predicting a red shift of the MLCT emission with deprotonation. This calculated trend is in agreement with luminescence spectra in acetonitrile solution at $22^{\circ} \mathrm{C}$ (Figure $\mathrm{S} 8, \mathrm{SI}$ ) showing a red shift of the MLCT emission band maximum by $370 \mathrm{~cm}^{-1}$ upon single deprotonation of biimH $\mathrm{b}_{2}$ to biimH $^{-}$. These comparisons show that it is likely that the pressure-induced red-shift observed for $\mathrm{Ru}\left({ }^{\mathrm{t}} \mathrm{Bu}\right)$ in the solid state is caused by a second-sphere effect.
Figure 2. Luminescence spectra of (a) $\mathrm{Ru}\left({ }^{t} \mathrm{Bu}\right)$ and $(\mathrm{b}) \mathrm{Ru}\left(\mathrm{CF}_{3}\right)$ as a function of hydrostatic pressure at room temperature. Excitation occurred at $488 \mathrm{~nm}$. (c) Energy of the MLCT luminescence band maxima $\left(E_{\max }\right)$ from (a) in circles and (b) in squares as a function of pressure. Least-squares fits show values of -13 $\pm 1 \mathrm{~cm}^{-1} / \mathrm{kbar}$ for $\mathrm{Ru}\left({ }^{\mathrm{t}} \mathrm{Bu}\right.$ ) (solid line) and $0 \mathrm{~cm}^{-1} / \mathrm{kbar}$ for $\mathrm{Ru}\left(\mathrm{CF}_{3}\right)$ (dotted line) with an average $E_{\max }$ value of $14120 \mathrm{~cm}^{-1}$. $E_{\max }$ at $0 \mathrm{kbar}$ for $\mathrm{Ru}\left({ }^{\mathrm{t}} \mathrm{Bu}\right)$ was calculated from an extrapolation of the $E_{\max }$ values at variable temperature (see $\mathrm{SI}$ on pages $\mathrm{S} 27$ and $\mathrm{S} 28)$. $\mathrm{E}_{\max }$ at $0 \mathrm{kbar}$ for $\mathrm{Ru}\left(\mathrm{CF}_{3}\right)$ was obtained from the spectrum at ambient temperature measured outside the pressure cell.

In the electron density map of the X-ray crystal structure of $\mathrm{Ru}\left({ }^{t} \mathrm{Bu}\right)$ at ambient pressure, the biim $\mathrm{H}_{2}$ ligand is fully protonated. Pressure is expected to shorten the two $\mathrm{N}-\mathrm{H} \cdots \mathrm{O}$ hydrogen bonds, making proton delocalization between the cationic $\mathrm{Ru}$ (II) complex and the counter-anion more readily possible, in analogy to what is observed for $\mathrm{Ru}\left(\mathrm{CF}_{3}\right)$ already at ambient pressure (Figure $1 \mathrm{~b} / \mathrm{d}$ ). In a previous study with a deuterated $\mathrm{N} \cdots \mathrm{H} \cdots \mathrm{O}$ hydrogen bond, $\mathrm{N}$... O distance decrease was accompanied by a net proton migration from $\mathrm{O}$ to $\mathrm{N}$ as observed crystallographically using averages over time. ${ }^{[11]}$ Delocalization was observed for hydrogen bonded benzoic acid at high pressure ${ }^{[12]}$ and is generally enhanced upon distance shortening. This is a result of the decrease distances between hydrogen bond donor and acceptor, which decreases the potential wells of the two discrete protonation states and increases proton transfer and tunneling rates.

Compression of single crystals of $\mathrm{Ru}\left({ }^{\mathrm{t}} \mathrm{Bu}\right)$ and $\mathrm{Ru}\left(\mathrm{CF}_{3}\right)$ induces similar shrinking of the respective unit cells by approximately 0.7 Vol-\%/kbar and $0.8 \mathrm{Vol}-\% / \mathrm{kbar}$, as seen in Tables S1 and S2 of the SI. Therefore, the change in the biimH $\mathrm{H}_{2}$ - carboxylate distance is expected to be similar in $\mathrm{Ru}\left(\mathrm{CF}_{3}\right)$ and in $\mathrm{Ru}\left({ }^{\mathrm{t}} \mathrm{Bu}\right)$ with increasing pressure. The transition from localized proton density to more delocalization in $\mathrm{Ru}\left({ }^{t} \mathrm{Bu}\right)$ seems to be the most important structural change. This effect is more important in $\mathrm{Ru}\left({ }^{\mathrm{t}} \mathrm{Bu}\right)$ compared to $\mathrm{Ru}\left(\mathrm{CF}_{3}\right)$ because in the latter structure the proton delocalization is already present (in both crystallographic isomers) from the beginning. Raman spectra at variable pressure (Figures S15 and S16 of the SI) show the expected minor frequency increases with pressure, indicating that the crystalline structures and phases remain stable at high pressures.

The control of second coordination sphere effects in artificial small complexes commonly requires substantial synthetic efforts, and in several cases remarkable results have been obtained. ${ }^{[2,13]}$ Our herein demonstrated approach is fundamentally different in that we use doubly hydrogen-bonded salt bridges as a motif to precisely place an anion in the second coordination sphere of two $\mathrm{Ru}$ (II) complexes in the solid state. Through external pressure, we are then able to continuously vary the hydrogen-bonding interaction. This concept should be readily applicable to a range of supramolecular structures with transition metal complexes and opens the possibility to explore and control second coordination sphere effects on luminescence and other electronic properties.

\section{Acknowledgements}

Financial support from the Natural Sciences and Engineering Research Council (NSERC) of Canada and the Fonds de Recherche Nature et Technologies du Québec (FRQNT) for 
research grants and graduate fellowships to S. P. and N. B.-D. is gratefully acknowledged. Financial support from the Swiss National Science Foundation through grant number 200021_156063/1 is acknowledged. We thank Diamond Light Source for access to beamline I19-2 (proposal number MT163141) and Dr. Dave R. Allan who contributed to the results presented herein as well as Sarah Keller and Y. Maximilian Klein for their support at I19-2.

Keywords: high-pressure chemistry • luminescence $\bullet$ hydrogen bonds $\bullet$ noncovalent interactions $\bullet$ supramolecular chemistry

[1] H. B. Gray, B. G. Malmström, R. J. P. Williams, J. Biol. Inorg. Chem. 2000, 5, 551-559.

[2] a) M. L. Helm, M. P. Stewart, R. M. Bullock, M. R. DuBois, D. L. DuBois, Science 2011, 333, 863-866; b) J. F. Hull, Y. Himeda, W. H. Wang, B. Hashiguchi, R. Periana, D. J. Szalda, J. T. Muckerman, E. Fujita, Nat. Chem. 2012, 4, 383-388; c) T. B. Liu, D. L. DuBois, R. M. Bullock, Nat. Chem. 2013, 5, 228-233; d) J. Y. Yang, S. E. Smith, T. Liu, W. G. Dougherty, W. A. Hoffert, W. S. Kassel, M. R. DuBois, D. L. DuBois, R. M. Bullock, J. Am. Chem. Soc. 2013, 135, 9700-9712; e) T. B. Rauchfuss, Acc. Chem. Res. 2015, 48, 2107-2116.

[3] a) T. K. Hyster, L. Knorr, T. R. Ward, T. Rovis, Science 2012, 338, 500-503; b) T. R. Ward, Acc. Chem. Res. 2011, 44, 47-57; c) H. M. Key, P. Dydio, D. S. Clark, J. F. Hartwig, Nature 2016, 534, 534-537; d) A. Rentmeister, F. H. Arnold, R. Fasan, Nat. Chem. Biol. 2009, 5, 26-28. a) Y. Z. Liu, C. H. Hu, A. Comotti, M. D. Ward, Science 2011, 333, 436-440; b) M. D. Ward, Chem. Commun. 2005, 5838-5842

[5] a) S. Fortin, A. L. Beauchamp, Inorg. Chem. 2001, 40, 105-112; b) S. Rau, L. Böttcher, S. Schebesta, M. Stollenz, H. Görls, D. Walther, Eur. J. Inorg. Chem. 2002 2800-2809; c) S. Rau, B. Schafer, S. Schebesta, A. Grussing, W. Poppitz, D. Walther, M. Duati, W. R. Browne,
J. G. Vos, Eur. J. Inorg. Chem. 2003, 1503-1506; d) Y. Cui, Y. L. Niu, M. L. Cao, K. Wang, H. J. Mo, Y. R. Zhong, B. H. Ye, Inorg. Chem. 2008, 47, 5616-5624; e) J. C. Freys, O. S. Wenger, Eur. J. Inorg. Chem. 2010, 55095516; f) O. S. Wenger, Chem.-Eur. J. 2011, 17, 11692$11702 ;$ g) S. A. Rommel, D. Sorsche, M. Fleischmann, S. Rau, Chem. Eur. J. 2017, 23, 18101-18119.

[6] a) A. M. Bond, M.-A. Haga, Inorg. Chem. 1986, 25, 45074514; b) M.-A. Haga, Inorg. Chim. Acta 1983, 75, 29-35; c) D. P. Rillema, R. Sahai, P. Matthews, A. K. Edwards, R. J. Shaver, L. Morgan, Inorg. Chem. 1990, 29, 167-175; d) J. C. Freys, G. Bernardinelli, O. S. Wenger, Chem. Commun. 2008, 4267-4269; e) S. A. Rommel, D. Sorsche, S. Rau, Dalton Trans. 2016, 45, 74-77.

[7] a) M. A. M. Lorente, F. Dahan, Y. Sanakis, V. Petrouleas, A. Bousseksou, J. P. Tuchagues, Inorg. Chem. 1995, 34 , 5346-5357; b) B. H. Ye, F. Xue, G. Q. Xue, L. N. Ji, T. C. W. Mak, Polyhedron 1999, 18, 1785-1790; c) B. H. Ye, B. B. Ding, Y. Q. Weng, X. M. Chen, Inorg. Chem. 2004, 43, 6866-6868.

[8] a) H. Yersin, E. Gallhuber, Inorg. Chem. 1984, 23, 37453748; b) Q. Sun, S. Mosquera-Vazquez, Y. Suffren, J. Hankache, N. Amstutz, L. M. Lawson Daku, E. Vauthey, A. Hauser, Coord. Chem. Rev. 2015, 282-283, 87-99.

[9] S. Poirier, L. Czympiel, N. Bélanger-Desmarais, S. Mathur, C. Reber, Dalton Trans. 2016, 45, 6574-6581.

[10] a) G. Gliemann, H. Yersin, Struct. Bonding 1985, 62, 87153; b) W. B. Connick, R. E. Marsh, W. P. Schaefer, H. B. Gray, Inorg. Chem. 1997, 36, 913-922; c) O. S. Wenger, S. Garcia-Revilla, H. U. Güdel, H. B. Gray, R. Valiente, Chem. Phys. Lett. 2004, 384, 190-192.

[11] T. Steiner, I. Majerz, C. C. Wilson, Angew. Chem. Int. Ed. 2001, 40, 2651-2654

[12] W. Z. Cai, A. Katrusiak, CrystEngComm 2012, 14, 44204424.

[13] M. Zhao, H. B. Wang, L. N. Ji, Z. W. Mao, Chem. Soc. Rev. 2013, 42, 8360-8375. 


\section{Entry for the Table of Contents}

Layout 2:

\section{COMMUNICATION}

Cation-anion adducts are squeezed together by hydrostatic pressure, leading to delocalization of protons in the hydrogen bonds between these cation-anion adducts and changes in the luminescence of $\mathrm{Ru}(\mathrm{II})$ complexes.

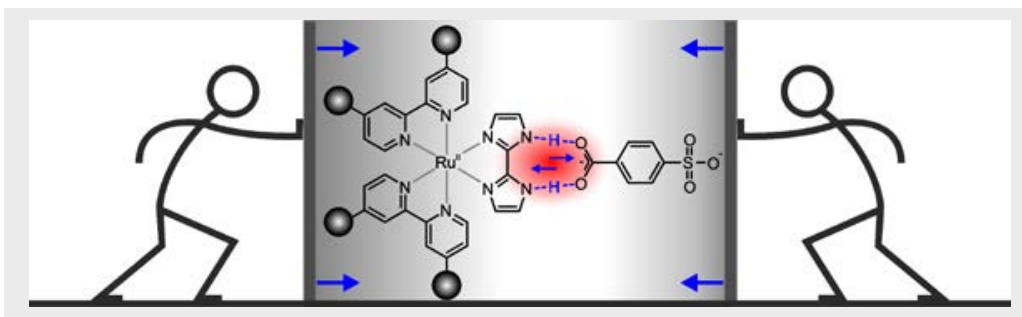

Andrea Pannwitz, Stéphanie Poirier, Nicolas Bélanger-Desmarais,

Alessandro Prescimone, Oliver S. Wenger, * Christian Reber*

Page No. - Page No.

Controlling second coordination sphere effects in luminescent ruthenium complexes by external pressure 